\title{
Lichen Myxedematosus Presenting as a Solitary Nodule
}

\author{
Myeong Heon Chae, Dae Hwi Eun, Ji Yeoun Lee, Tae Young Yoon \\ Department of Dermatology, Chungbuk National University College of Medicine, Cheongju, Korea
}

\section{Dear Editor:}

Lichen myxedematosus (LM) is characterized by diffuse mucin deposition with fibroblast proliferation in the dermis. It clinically manifests small, discrete papules on the trunk and extremities ${ }^{1,2}$. Nodular LM is very rare. There has been no report of nodular LM in the Korean literature.

A 74-year-old Korean female presented with an asymptomatic growing nodule on the lateral side of the right upper thigh for one year. Her past medical history included spinal stenosis. She had no medical history of connective tissue diseases, such as systemic lupus erythematosus or dermatomyositis. There was no trauma history. Physical examination revealed a flesh-colored, firm nodule of $7 \mathrm{~cm}$ in diameter on her lateral side of the right upper thigh with some brownish papules on its surface (Fig. 1A). Laboratory findings for complete blood count, liver, and renal function tests were normal. Test for thyroid function was normal. Human immunodeficiency virus was negative. Serum protein electrophoresis test and urinalysis were also normal. Skin biopsy was done for a flesh-colored nodule and a brownish papule on the right thigh. Histologically, both lesions showed diffuse mucin deposition with fibroblast proliferation in the upper and mid dermis without remarkable fibrosis (Fig. 1B, C). A mild perivascular lymphocytic infiltrate was observed in the upper dermis, and there was

Received April 1, 2019, Revised May 21, 2019, Accepted for publication June 25, 2019

Comesponding author: Tae Young Yoon, Department of Dermatology, Chungbuk National University College of Medicine, 1 Chungdae-ro, Seowon-gu, Cheongju 28644, Korea. Tel: 82-43-269-6369, Fax: 82-43-266-1698, E-mail: tyyoon@ chungbuk.ac.kr

ORCID: https://orcid.org/0000-0001-6947-1853

This is an Open Access article distributed under the terms of the Creative Commons Attribution Non-Commercial License (http://creativecommons. org/licenses/by-nc/4.0) which permits unrestricted non-commercial use, distribution, and reproduction in any medium, provided the original work is properly cited.

Copyright $($ c The Korean Dermatological Association and The Korean Society for Investigative Dermatology no mast cell proliferation. Based on the clinical and histological findings, a diagnosis of nodular LM was made. She did not want to be treated. She is currently under observation for five months without showing changes in the size of the lesion.

LM is an idiopathic cutaneous mucinosis that is not associated with thyroid disease ${ }^{1,2}$. It is largely divided into two categories: (1) a generalized form, also called scleromyxedema, with a monoclonal gammopathy and visceral organ involvement; and (2) a localized form which is usually confined to the skin following a benign disease course ${ }^{1,2}$. Localized LM is further divided into four subtypes according to clinical features: (1) discrete papular form, (2) acral persistent papular mucinosis, (3) cutaneous mucinosis of infancy, and (4) pure nodular form ${ }^{2}$, like our case. LM has typical histological features of dermal mucin deposition with variable fibroblast proliferation. For the diagnosis of localized LM, aforementioned clinicopathological features must be shown without accompanying thyroid disease, paraproteinemia, or systemic involvement ${ }^{1,2}$.

Nodular LM is very rare. Only five such cases have been previously reported in the English literature (Table 1$)^{3-5}$. Previously reported cases of nodular LM showed clinical features of multiple scattered small nodules. However, the nodular lesion in our case appeared solitary and the size of the lesion was much larger $(7.0 \mathrm{~cm})$ than that of previously reported cases $(0.3$ to $2.0 \mathrm{~cm})$.

Generally, localized LM does not require treatment because of their benign nature. Spontaneous resolution may also occur ${ }^{1,2}$. Systemic therapy with methotrexate or intralesional corticosteroid injection may have some benefit for nodular $\mathrm{LM}^{3,5}$.

Dermatologists should be aware of this rare subtype of LM. If suspected, appropriate histologic and laboratory examinations should be performed in order to rule out possible paraproteinemia or systemic involvement early. 

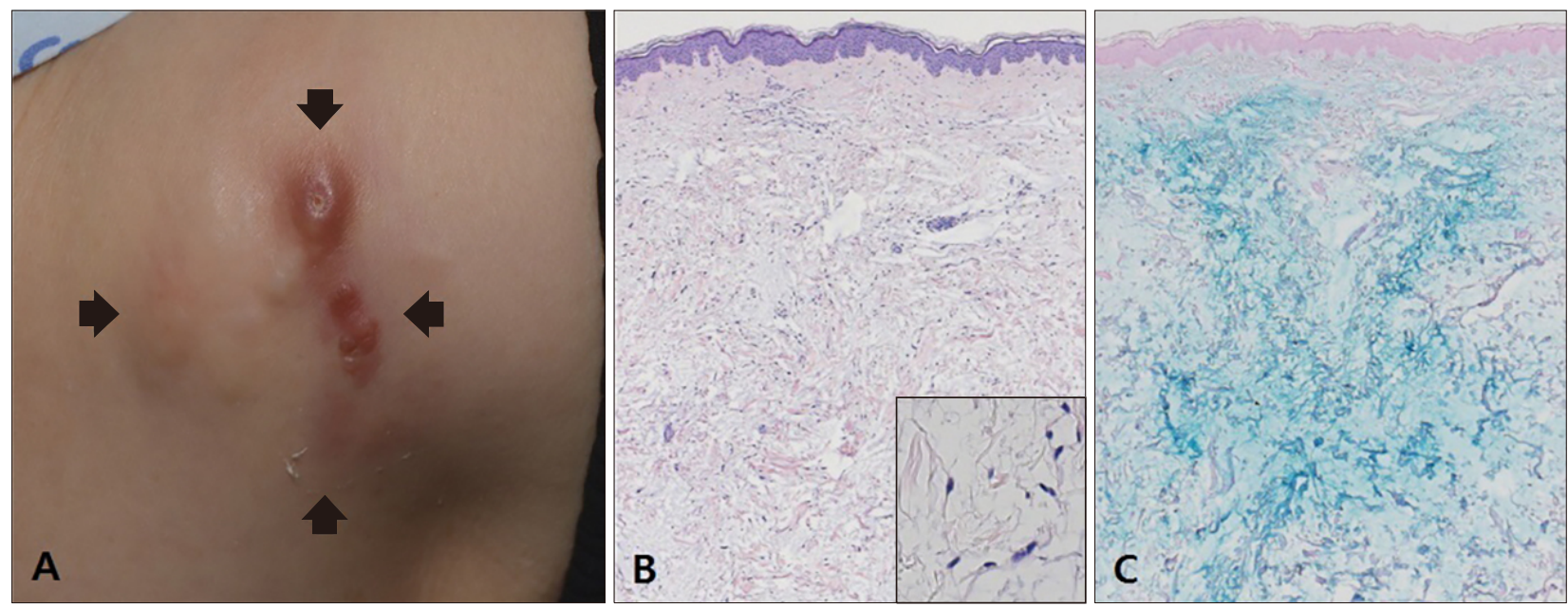

Fig. 1. (A) A flesh-colored solitary nodule on the lateral side of the right upper thigh with some brownish papules on its surface. (B, C) Diffuse mucin deposition with fibroblast proliferation in the upper and mid dermis without remarkable fibrosis $(B$ : $\mathrm{H} \& \mathrm{E}, \times 40$ [inset: $\mathrm{H} \& \mathrm{E}, \times 200] ; \mathrm{C}:$ Alcian blue at $\mathrm{pH} 2.5, \times 40$ ). We received the patient's consent form about publishing all photographic materials.

Table 1. Previously reported cases of nodular lichen myxedematosus

\begin{tabular}{|c|c|c|c|c|c|c|}
\hline Study & Age $(y r) / s e x$ & Location & $\begin{array}{c}\text { Shape/ } \\
\text { arrangement }\end{array}$ & $\begin{array}{l}\text { Size } \\
(\mathrm{cm})\end{array}$ & Symptom & Treatment \\
\hline Our case & 74/female & Right thigh & Nodule/solitary & 7.0 & No & Observation \\
\hline $\begin{array}{l}\text { Ferris et al. }{ }^{3} \\
(2016)\end{array}$ & 45/female & $\begin{array}{l}\text { Trunk, right upper } \\
\text { arm, both wrists }\end{array}$ & Nodule/scattered & NA & Tenderness & Methotrexate (partial regression) \\
\hline $\begin{array}{l}\text { Zeng et } \text { al. }^{4} \\
\text { (2014) }\end{array}$ & 6/male & $\begin{array}{l}\text { Trunk, right upper } \\
\text { arm, right thigh }\end{array}$ & Nodule/scattered & $1.0 \sim 2.0$ & No & $\begin{array}{l}\text { Tacrolimus ointment } \\
\text { (not effective) }\end{array}$ \\
\hline $\begin{array}{l}\text { Ogita et al. } \\
(2010)\end{array}$ & 18/female & $\begin{array}{l}\text { Both forearms, } \\
\text { left cubital fossa, } \\
\text { left thigh }\end{array}$ & Nodule/scattered & $0.6 \sim 1.0$ & No & $\begin{array}{l}\text { Triamcinolone intralesional } \\
\text { injection (complete regression) }\end{array}$ \\
\hline $\begin{array}{l}\text { Schneider et al. } \\
\text { (1991) }\end{array}$ & $32 /$ male & $\begin{array}{l}\text { Trunk, } \\
\text { right upper arm }\end{array}$ & Nodule/scattered & $0.5 \sim 2.0$ & No & Observation \\
\hline $\begin{array}{l}\text { Suter et al. } \\
(1980)\end{array}$ & 48/male & Both thighs & Nodule/scattered & $0.3 \sim 1.5$ & No & $\begin{array}{l}\text { Hyaluronidase intralesional } \\
\text { injection (partial regression) }\end{array}$ \\
\hline
\end{tabular}

NA: not available.

\section{CONFLICTS OF INTEREST}

The authors have nothing to disclose.

\section{ORCID}

Myeong Heon Chae, https://orcid.org/0000-0003-2107-6592

Dae Hwi Eun, https://orcid.org/0000-0001-5057-7199

Ji Yeoun Lee, https://orcid.org/0000-0001-9269-6591

Tae Young Yoon, https://orcid.org/0000-0001-6947-1853

\section{REFERENCES}

1. Rongioletti F, Rebora A. Updated classification of papular mucinosis, lichen myxedematosus, and scleromyxedema. J Am Acad Dermatol 2001;44:273-281.

2. Rongioletti F. Lichen myxedematosus (papular mucinosis): new concepts and perspectives for an old disease. Semin Cutan Med Surg 2006;25:100-104.

3. Ferris GJ, Spohn GP, Gru A, Kaffenberger J. Mucin in the dermis: a case of tender tumors. Dermatol Online J 2016; 22:13030/qt4b50f4zf.

4. Zeng R, Li M, Jiang Y, Liu W. Nodular lichen myxedematosus during childhood: a case report. Pediatr Dermatol 2014;31:e160-e163.

5. Ogita A, Higashi N, Hosone M, Kawana S. Nodular-type lichen myxedematosus: a case report. Case Rep Dermatol 2010;2:195-200. 